\title{
Influence of micronutrients on dry matter yield and interaction with other nutrients in annual crops ${ }^{(1)}$
}

\author{
Nand Kumar Fageria ${ }^{(2)}$
}

\begin{abstract}
The objective of this work was to determine the influence of $\mathrm{Zn}, \mathrm{Mn}$ and $\mathrm{Cu}$ on shoot dry matter yield and uptake of macro and micronutrients in upland rice, common bean and corn. Six greenhouse experiments were conducted using a Dark Red Latosol (Typic Haplusthox). Treatments consisted of application of $\mathrm{Zn}$ at 0, 5, 10, 20, 40, 80 and $120 \mathrm{mg} \mathrm{kg}^{-1}$, of Mn at 0, 10, 20, 40, 80, 160, 320 and $640 \mathrm{mg} \mathrm{kg}^{-1}$ and of $\mathrm{Cu}$ application at $0,2,4,8,32,64$ and $96 \mathrm{mg} \mathrm{kg}^{-1}$. Zinc increased yield of rice, $\mathrm{Mn}$ increased yields of corn and bean and $\mathrm{Cu}$ improved yields of rice and bean. Uptake of $\mathrm{N}, \mathrm{Ca}$, and $\mathrm{Cu}$ in rice was decreased by zinc treatment. In common bean, uptake of $\mathrm{N}, \mathrm{Mg}$, and $\mathrm{Cu}$ was increased by zinc application, whereas, uptake of $\mathrm{P}$ was decreased. Manganese increased uptake of $\mathrm{Mg}, \mathrm{Zn}$ and $\mathrm{Fe}$ and decreased uptake of $\mathrm{Ca}$, in corn. Uptake of $\mathrm{K}, \mathrm{Zn}$ and $\mathrm{Mn}$ was increased and uptake of $\mathrm{P}$ and $\mathrm{Cu}$ was decreased by $\mathrm{Mn}$ application, in bean. Copper had positive and negative interactions in the uptake of macro and micronutrients, depending on crop species and nutrients involved.
\end{abstract}

Index terms: cerrado soils, nutrient uptake, cereal crops, yields.

\section{Influência de micronutrientes na produção de matéria seca e interação com outros nutrientes em culturas anuais}

\begin{abstract}
Resumo - O objetivo deste trabalho foi determinar a influência do Zn, Mn e Cu na produção de matéria seca e na absorção de nutrientes pelo arroz de terras altas, feijoeiro e milho. Foram conduzidos seis experimentos em casa de vegetação, num Latossolo Vermelho-Escuro. Os tratamentos constituíram-se de $0,5,10,20,40,80$ e $120 \mathrm{mg} \mathrm{kg}^{-1}$ de Zn, 0, 10, 20, 40, 80, 160, 320 e $640 \mathrm{mg} \mathrm{kg}^{-1}$ de Mn e 0, 2, 4, 8, $32,64 \mathrm{e} 96 \mathrm{mg} \mathrm{kg}^{-1}$ de cobre. $\mathrm{O} \mathrm{Zn}$ aumentou a produção de arroz, o Mn aumentou a produção de milho e feijão, e o Cu aumentou a produção de arroz e feijão. O Zn diminuiu a absorção de $\mathrm{N}$, $\mathrm{Ca}$ e Cu pelo arroz. No feijoeiro, o $\mathrm{Zn}$ aumentou a absorção de $\mathrm{N}, \mathrm{Mg}$ e $\mathrm{Cu}$ e diminuiu a absorção de fósforo. No milho, o Mn aumentou a absorção de Mg, Zn e Fe e diminuiu a absorção de cálcio. A absorção de K, Zn e Mn aumentou no feijoeiro com a aplicação de $\mathrm{Mn}$, porém, a absorção de $\mathrm{P}$ e $\mathrm{Cu}$ diminuiu. $\mathrm{O} \mathrm{Cu}$ mostrou efeitos positivo e negativo na absorção de macro e micronutrientes dependendo das espécies e nutrientes envolvidos.
\end{abstract}

Termos para indexação: solo de cerrado, absorção de nutriente, cultivo de cereais, rendimento.

\section{Introduction}

The importance of micronutrients in crop production is increasing in recent years due to use of high yielding cultivars, intensive cropping systems, and liming of acid soils. Most of the cerrado soils are acidic and liming is an essential practice to improve soil $\mathrm{pH}$ and decrease toxicity of $\mathrm{Al}^{3+}$ (Fageria \& Baligar, 2001; Ernani et al., 2002). Liming significantly

\footnotetext{
(1) Accepted for publication on July 12, 2002.

(2) Embrapa-Centro Nacional de Pesquisa de Arroz e Feijão, Caixa Postal 179, CEP 75375-000 Santo Antônio de Goiás, GO, Brazil. E-mail: fageria@cnpaf.embrapa.br
}

increases grain yields of annual crops such as common bean, soybean, and corn grown on Oxisols of cerrado (Barbosa Filho \& Silva, 2000; Fageria \& Baligar, 2001). However, liming decreases uptake of all micronutrients except Mo (Fageria et al., 1997). Hence, liming may induce micronutrients deficiencies. Fageria (2000) reported Fe deficiency in upland rice when $\mathrm{pH}$ of cerrado soil was raised more than 6.0 by liming. This means requirements of crops for micronutrients change, when these soils are limed to produce good yields of legumes like common bean and soybean. Deficiencies of micronutrientes in cerrado soils had been widely reported in annual crops (Galrão, 1984, 1991; Couto et al., 1992; Couto 
\& Klamt, 1999; Galrão, 1999; Oliveira Júnior et al., 2000; Fageria et al., 2002).

Nutrient interaction in crop plants is probably one of the most important factors affecting yields of annual crops. Nutrient interaction can be either positive, negative or neutral (Fageria et al., 1997). It can be measured in terms of crop growth and nutrient concentrations in plant tissue. Soil, plant and climatic factors can influence interaction. In the nutrient interaction studies, all other factors should be at an optimum level, except the variation in level of the nutrient under investigation. Nutrient interaction can occur at the root surface or within the plant. Interactions at the root surface are due to formation of chemical bonds by ions and precipitation or complexes. One example of this type of the interaction is the decrease in the concentration of $\mathrm{Fe}, \mathrm{Zn}, \mathrm{Cu}$ and $\mathrm{Mn}$ with liming of acid soils (Fageria, 2000; Fageria et al., 2002). The second type of interaction is between ions whose chemical properties are sufficiently similar and they compete for site of absorption, transport, and function on plant root surface or within plant tissues. Such interactions are more common between nutrients of similar size, charge and geometry of coordination and electronic configuration (Robson \& Pitman, 1983).

Interactions vary from nutrient to nutrient, from crop species to species and sometimes among cultivars of the same species. Therefore, this is a very complex issue in mineral nutrition and not well understood in annual crops grown on Oxisols. Information on response of annual crops to micronutrients grown on cerrado soils to micronutrients and influence of micronutrients on uptake of other nutrients is limited.

The objective of this research was to determine the influence of zinc, manganese and copper on shoot dry matter yield and uptake of macro and micronutrients in upland rice, common bean and corn grown on an Oxisol.

\section{Material and Methods}

\section{Zinc experiments}

Two greenhouse experiments were conducted at the Embrapa-Centro Nacional de Pesquisa de Arroz e Feijão, Santo Antônio de Goiás, GO, Brazil, to study the interac- tion of zinc with other nutrients in upland rice (Oryza sativa $\mathrm{L}$.) and common bean (Phaseolus vulgaris $\mathrm{L}$.) grown on a Dark Red Latosol (Typic Haplusthox). Chemical properties of soil used in these experiments were: $\mathrm{pH} 5.7$ in water (1:2.5); $\mathrm{P}, 0.6 \mathrm{mg} \mathrm{kg}^{-1} ; \mathrm{K}, 53 \mathrm{mg} \mathrm{kg}^{-1} ; \mathrm{Ca}, 2 \mathrm{cmol}_{\mathrm{c}} \mathrm{kg}^{-1}$; $\mathrm{Mg}, 0.4 \mathrm{cmol}_{\mathrm{c}} \mathrm{kg}^{-1} ; \mathrm{Al}, 0.1 \mathrm{cmol}_{\mathrm{c}} \mathrm{kg}^{-1} ; \mathrm{Cu}, 1.7 \mathrm{mg} \mathrm{kg}^{-1} ; \mathrm{Zn}$, $0.9 \mathrm{mg} \mathrm{kg}^{-1} ; \mathrm{Fe}, 112 \mathrm{mg} \mathrm{kg}^{-1} ; \mathrm{Mn}, 10 \mathrm{mg} \mathrm{kg}^{-1}$ and organic matter $17 \mathrm{~g} \mathrm{~kg}^{-1}$. Textural analysis was clay, $385 \mathrm{~g} \mathrm{~kg}^{-1}$; silt, $265 \mathrm{~g} \mathrm{~kg}^{-1}$ and sand, $350 \mathrm{~g} \mathrm{~kg}^{-1}$. Phosphorus, $\mathrm{K}$ and the micronutrients were extracted by the Mehlich 1 extracting solution $\left(0.05 \mathrm{M} \mathrm{HCl}+0.0125 \mathrm{M} \mathrm{H}_{2} \mathrm{SO}_{4}\right)$. The $\mathrm{P}$ was determined colorimetrically, $\mathrm{K}$ by flame photometry, and micronutrients by atomic absorption spectrophotometry. The $\mathrm{Ca}, \mathrm{Mg}$, and $\mathrm{Al}$ were extracted with $1 \mathrm{M} \mathrm{KCl}$. The $\mathrm{Al}$ was determined by titration with $\mathrm{NaOH}$, and $\mathrm{Ca}$ and $\mathrm{Mg}$ by titration with EDTA. Organic matter was determined by the Walkley-Black method in which oxidizable matter in a soil sample is oxidized by $1 \mathrm{~N} \mathrm{~K}_{2} \mathrm{Cr}_{2} \mathrm{O}_{7}$ and $\mathrm{H}_{2} \mathrm{SO}_{4}$ solution and titration with standard $\mathrm{FeSO}_{4}$ solution. Detailed descriptions of all the soil analysis methods are given in the Soil Analysis Manual (Embrapa, 1997).

Experiments were conducted in plastic pots with $5 \mathrm{~kg}$ of soil in each pot. Zinc levels used were 0, 5, 10, 20, 40, 80 , and $120 \mathrm{mg} \mathrm{kg}^{-1}$ of soil applied as $\mathrm{Zn}$ sulfate. Each pot received $400 \mathrm{mg} \mathrm{N}$ as ammonium sulfate, $983 \mathrm{mg} P$ as triple superphosphate and $896 \mathrm{mg} \mathrm{K}$ as potassium chloride. Experimental design was complete block with three replications and four plants in each pot. Rice plants were harvested 42 days after sowing and common bean plants were harvested 35 days after sowing.

\section{Manganese experiments}

Two greenhouse experiments were conducted to study influence of $\mathrm{Mn}$ on uptake of nutrients in corn and common bean plants. The soil used in two experiments was a Dark Red Latosol (Typic Haplusthox). Before application of Mn treatments, the soil used in the two experiments had the following chemical properties: $\mathrm{pH}, 5.5 ; \mathrm{Ca}$, $2 \mathrm{cmol}_{\mathrm{c}} \mathrm{kg}^{-1} ; \mathrm{Mg}, 1.3 \mathrm{cmol}_{\mathrm{c}} \mathrm{kg}^{-1} ; \mathrm{Al}, 0.2 \mathrm{cmol}_{\mathrm{c}} \mathrm{kg}^{-1} ; \mathrm{P}$, $9 \mathrm{mg} \mathrm{kg}^{-1} ; \mathrm{K}, 44 \mathrm{mg} \mathrm{kg}^{-1} ; \mathrm{Cu}, 0.9 \mathrm{mg} \mathrm{kg}^{-1} ; \mathrm{Zn}, 4 \mathrm{mg} \mathrm{kg}^{-1}$; $\mathrm{Fe}, 53 \mathrm{mg} \mathrm{kg}^{-1}$; Mn, $8 \mathrm{mg} \mathrm{kg}^{-1}$ and organic matter content of $20 \mathrm{~g} \mathrm{~kg}^{-1}$. Soil analysis methods was the same as described above in the zinc experiments.

Eight rates of $\mathrm{Mn}$ were applied through manganese sulfate for corn, to create different levels of soil manganese. These Mn rates were $0,10,20,40,80,160,320$, and $640 \mathrm{mg} \mathrm{kg}^{-1}$. For common bean, Mn levels used were $0,10,20,40,80,160$, and $320 \mathrm{mg} \mathrm{kg}^{-1}$ of soil and were also applied through manganese sulfate. The experiments were conducted in plastic pots with each pot contained $5 \mathrm{~kg}$ of soil. Each pot also received $400 \mathrm{mg} \mathrm{N}$ through 
$\left(\mathrm{NH}_{4}\right)_{2} \mathrm{SO}_{4}, 787 \mathrm{mg} \mathrm{P}$ through triple superphosphate, and $797 \mathrm{mg} \mathrm{K}$ through KCl. These basal fertilizer rates were based on an earlier work (Fageria \& Baligar, 1997). The experiment design in two experiments was a complete block with three replications. There were four plants per pot in both experiments and soil moisture was maintained approximately at field capacity. Plants were harvested four weeks after sowing in both experiments.

\section{Copper experiments}

Two greenhouse experiments were conducted to evaluate interaction of $\mathrm{Cu}$ with other nutrients in the upland rice and common bean. The soil used in these two experiments was a Dark Red Latosol (Typic Haplusthox). Before application of $\mathrm{Cu}$ treatments, the soil used in two experiments had the following chemical properties: $\mathrm{pH}, 5.3$; $\mathrm{Ca}, 0.3 \mathrm{cmol}_{\mathrm{c}} \mathrm{kg}^{-1} ; \mathrm{Mg}, 0.4 \mathrm{cmol}_{\mathrm{c}} \mathrm{kg}^{-1} ; \mathrm{Al}, 0.6 \mathrm{cmol}_{\mathrm{c}} \mathrm{kg}^{-1}$; $\mathrm{P}, 0.4 \mathrm{mg} \mathrm{kg}^{-1} ; \mathrm{K}, 23 \mathrm{mg} \mathrm{kg}^{-1} ; \mathrm{Cu}, 1 \mathrm{mg} \mathrm{kg}^{-1} ; \mathrm{Zn}, 0.5 \mathrm{mg} \mathrm{kg}^{-1}$; $\mathrm{Fe}, 65 \mathrm{mg} \mathrm{kg}^{-1}$; Mn, $17 \mathrm{mg} \mathrm{kg}^{-1}$, and organic matter content of $15 \mathrm{~g} \mathrm{~kg}^{-1}$. Methods used in these experiments for soil analysis were similar to those given in the zinc experiments.

The $\mathrm{Cu}$ levels used were $0,2,4,8,16,32,64$, and $96 \mathrm{mg} \mathrm{kg}^{-1}$ of soil applied as copper sulfate. Before application of $\mathrm{Cu}$ treatments and basal fertilization, each pot received $23 \mathrm{~g}$ dolomitic lime and were incubated for four weeks. The lime used had $\mathrm{CaO} 30.8 \%, \mathrm{MgO} 18.4 \%$, $\mathrm{CaCO}_{3} 55 \%, \mathrm{MgCO}_{3} 38.6 \%$, and neutralizing power of $\mathrm{CaCO}_{3} 87 \%$. This lime rate was selected on the basis of earlier work in which soil $\mathrm{pH}$ of 5.1 was increased to 6.0 with the application of this rate and $\mathrm{pH} 6.0$ was established as an optimum value for the growth of most crop species (Fageria et al., 1997). In the Cu experiments, rice plants were harvested four weeks after sowing, whereas, common bean plants were harvested three weeks after sowing. The experiment design in two experiments was a complete block with three replications.

In $\mathrm{Zn}, \mathrm{Mn}$ and $\mathrm{Cu}$ experiments, after harvesting, the shoots were washed with distilled water several times before drying. Plant material was dried in a forced draft oven at about $70^{\circ} \mathrm{C}$ to constant weight, and was milled. Ground material was digested with mixtures of nitric and perchloric acids (2:1). In the digested material, $\mathrm{P}$ was determined colorimetrically and the other nutrients were analyzed by atomic absorption spectroscopy (Moraes \& Rabelo, 1986). For $\mathrm{N}$ determination, dried plant material was digested with sulfuric acid and was analyzed by a semimicroKjeldahl method (Bremner \& Mulvaney, 1982) using a Kjeltec Systems Tecator 1016 digesting and distilling unit.

Data were analyzed by analysis of variance and appropriate regression models selected on the basis of higher $\mathrm{R}^{2}$ values were adjusted to evaluate treatment effects. In quantitative treatments such as levels of micronutrients, regression analysis is a more appropriate statistical technique to evaluate treatment effects. Therefore, for discussion purpose, regression analysis was taken into account to evaluate treatment effects.

\section{Results and Discussion}

Data related to the influence of $\mathrm{Zn}$ application on dry matter yield of upland rice and common bean and uptake of macro and micronutrients are presented in Table 1. Dry matter yield of upland rice was significantly increased with the Zn application, however, yield of common bean had significant negative influence of Zn application. Many workers (Fageria et al., 1997; Fageria et al., 2002) have reported positive influence of $\mathrm{Zn}$ on upland rice yield in Brazilian Oxisols. Increasing $\mathrm{Zn}$ concentration in the soil significantly improves uptake of $\mathrm{Zn}$ in rice as well as common bean plants as expected. Rice plants had much higher concentration of $\mathrm{Zn}$ as compared to bean plants. This means $\mathrm{Zn}$ requirement for rice is much higher as compared to common bean plants grown on an Oxisol. The differences between crop species and between cultivars within species in $\mathrm{Zn}$ uptake and utilization have been widely reported (Cakmak et al., 1998; Baligar \& Fageria, 2001). This may be related to a better internal utilization of $\mathrm{Zn}$ in bean plants leading to a higher growth rate at low internal Zn concentration as compared to rice plants. These results also indicate that upland rice can tolerate much higher concentration of $\mathrm{Zn}$ as compared to bean plants. Fageria et al. (2002) reported critical toxic level much higher in rice plants as compared to common bean plants. Uptake of $\mathrm{N}$ and $\mathrm{Cu}$ was significantly decreased in rice plants. In common bean, application of Zn significantly improved uptake of $\mathrm{N}, \mathrm{Mg}$ and copper. However, Zn had significant negative interaction with $\mathrm{P}$ uptake. Zinc and $\mathrm{P}$ interactions have been reported positive as well as negative (Sumner \& Farina, 1986; Wilkinson et al., 2000). Data related to interactions of $\mathrm{Zn}$ with other nutrients are scarce and therefore it is not possible to compare results of this study with those reported in the literature.

Response and interactions of manganese with other nutrients were studied in corn and common 
bean and results are presented in Table 2. Manganese application significantly increased corn as well as common bean dry matter yield. In Oxisols of central Brazil, liming generally induce micronutrient deficiencies and Mn application improved yield of annual crops (Novais et al., 1989). Manganese application significantly increased Mn uptake in corn and common bean plants. However, it was much higher in common bean plants especially at higher Mn levels. This means Mn requirement for common bean is higher as compared to corn.

Manganese application significantly improved uptake of $\mathrm{Mg}, \mathrm{Zn}$ and $\mathrm{Mn}$ in corn. However, uptake of $\mathrm{Ca}$ and $\mathrm{Fe}$ was significantly decreased with the addition of $\mathrm{Mn}$ in the growth medium. Chinnery \& Harding (1980) have reported antagonistic effect of $\mathrm{Mn}$ on the uptake of Fe and vice-versa. They reported that concentration of $\mathrm{Mn}$ in the soybean shoots decreased with increased $\mathrm{Fe}$ concentration in the solution, probably an oxidation of Fe by manganese. Leach \& Taper (1954) concluded that the optimum $\mathrm{Fe} / \mathrm{Mn}$ ratios in plants ranged from 1.5 to 3.0 for kidney bean and from 0.5 to 5.0 for tomato. Iron deficiency developed at lower ratios and $\mathrm{Mn}$ toxicity at higher ratios. This means, antagonistic interaction between $\mathrm{Mn}$ and $\mathrm{Fe}$ has some practical implications. For example Fe toxicity is very common in flooded rice due to reduced conditions and $\mathrm{Mn}$ toxicity is common in legumes in acid soils when $\mathrm{pH}$ is lower than 5.5 (Fageria et al., 1997). Therefore, Fe toxicity in flooded rice can be reduced by Mn application and Mn toxicity in acid soil can be minimized by Fe application. There was no significant effect of $\mathrm{Mn}$ on uptake of $\mathrm{P}, \mathrm{K}$, and $\mathrm{Cu}$ in corn plants. In common bean plants, Mn addition had significant synergistic effect on the uptake of $\mathrm{K}, \mathrm{Zn}$ and manganese. But Mn had antagonistic effect on uptake of $\mathrm{P}$ and $\mathrm{Cu}$ in common bean plants.

Table 1. Influence of zinc on dry matter yield and uptake of macronutrients and micronutrients by upland rice and common bean plants.

\begin{tabular}{|c|c|c|c|c|c|c|c|c|c|c|}
\hline $\mathrm{Zn}$ & Shoot dry wt. & $\mathrm{N}$ & $\mathrm{P}$ & $\mathrm{K}$ & $\mathrm{Ca}$ & $\mathrm{Mg}$ & $\mathrm{Zn}$ & $\mathrm{Cu}$ & $\mathrm{Mn}$ & $\mathrm{Fe}$ \\
\hline & & \multicolumn{9}{|c|}{ Upland rice } \\
\hline 0 & 1.73 & 42.75 & 2.25 & 28.50 & 7.32 & 4.05 & 28 & 13 & 1,075 & 115 \\
\hline 5 & 2.05 & 42.25 & 2.20 & 29.00 & 6.75 & 3.77 & 71 & 14 & 740 & 125 \\
\hline 10 & 2.35 & 40.50 & 2.20 & 30.25 & 6.82 & 3.80 & 87 & 12 & 663 & 135 \\
\hline 20 & 2.15 & 41.50 & 1.87 & 30.75 & 6.95 & 3.75 & 125 & 12 & 643 & 113 \\
\hline 40 & 2.13 & 39.50 & 2.20 & 25.50 & 6.40 & 3.55 & 363 & 12 & 785 & 115 \\
\hline 80 & 1.97 & 37.50 & 2.27 & 25.50 & 6.47 & 3.77 & 718 & 11 & 593 & 128 \\
\hline 120 & 1.53 & 40.25 & 2.15 & 25.75 & 6.32 & 3.50 & 863 & 10 & 440 & 103 \\
\hline F test & *** & $* *$ & $\mathrm{~ns}$ & $*$ & $* *$ & $* *$ & $* *$ & $* *$ & $* *$ & ns \\
\hline $\mathrm{CV}(\%)$ & 10 & 2 & 8 & 10 & 5 & 4 & 18 & 6 & 24 & 18 \\
\hline \multicolumn{11}{|l|}{ Regression } \\
\hline$\beta_{0}$ & 1.9770 & 42.7362 & 2.1607 & 29.9250 & 7.0708 & 3.8849 & -4.3774 & 13.1163 & 846.6214 & 120.2178 \\
\hline$\beta_{1}$ & 0.00988 & -0.12598 & -0.00048 & -0.08676 & -0.01602 & -0.00591 & 10.40388 & -0.03553 & -4.48579 & 0.17951 \\
\hline$\beta_{2}$ & -0.00011 & 0.00086 & 0.000006 & 0.00042 & 0.00008 & 0.00003 & -0.02510 & 0.00008 & 0.01074 & -0.00248 \\
\hline $\mathrm{R}^{2}$ & $0.6693^{*}$ & $0.8582^{*}$ & $0.11^{\mathrm{ns}}$ & $0.6161^{\mathrm{ns}}$ & $0.7232^{*}$ & $0.5149^{\mathrm{ns}}$ & $0.9864^{* *}$ & $0.8012^{*}$ & $0.5495^{\mathrm{ns}}$ & $0.3096^{\mathrm{ns}}$ \\
\hline \multicolumn{11}{|c|}{ Common bean } \\
\hline 0 & 5.37 & 41.00 & 1.80 & 24.25 & 19.20 & 8.22 & 17 & 4.75 & 108 & 125 \\
\hline 5 & 5.33 & 40.00 & 1.82 & 22.25 & 19.52 & 8.20 & 56 & 4.50 & 108 & 115 \\
\hline 10 & 5.27 & 40.25 & 1.45 & 23.25 & 20.65 & 8.37 & 73 & 5.00 & 128 & 140 \\
\hline 20 & 5.02 & 41.25 & 1.32 & 27.00 & 19.85 & 8.40 & 92 & 4.75 & 93 & 95 \\
\hline 40 & 4.67 & 40.50 & 1.10 & 22.50 & 21.45 & 8.45 & 150 & 5.50 & 123 & 150 \\
\hline 80 & 4.67 & 40.75 & 1.05 & 24.50 & 18.87 & 8.02 & 215 & 5.00 & 125 & 133 \\
\hline 120 & 3.97 & 38.50 & 1.02 & 21.25 & 18.70 & 7.72 & 313 & 4.25 & 120 & 133 \\
\hline F test & $\mathrm{ns}$ & $\mathrm{ns}$ & $* *$ & $\mathrm{~ns}$ & $\mathrm{~ns}$ & $\mathrm{~ns}$ & $* *$ & $\mathrm{~ns}$ & $\mathrm{~ns}$ & $\mathrm{~ns}$ \\
\hline CV (\%) & 13 & 7 & 15 & 13 & 9 & 6 & 27 & 21 & 19 & 18 \\
\hline \multicolumn{11}{|l|}{ Regression } \\
\hline$\beta_{0}$ & 5.3385 & 40.3737 & 1.7625 & 23.5014 & 19.6611 & 8.2587 & 35.5717 & 4.6029 & 108.3553 & 119.2847 \\
\hline$\beta_{1}$ & -0.01206 & 0.02868 & -0.01990 & 0.04532 & 0.03232 & 0.00599 & 2.79364 & 0.02542 & 0.30915 & 0.41045 \\
\hline$\beta_{2}$ & 0.00001 & -0.00036 & 0.00011 & -0.00052 & -0.00036 & -0.00009 & -0.00441 & -0.00023 & -0.00167 & -0.00248 \\
\hline $\mathrm{R}^{2}$ & $0.9267^{* *}$ & $0.7272^{*}$ & $0.9269^{* *}$ & $0.2810^{\mathrm{ns}}$ & $0.4447^{\text {ns }}$ & $0.8822^{*}$ & $0.9864^{* *}$ & $0.7387^{*}$ & $0.2001^{\mathrm{ns}}$ & $0.1280^{\mathrm{ns}}$ \\
\hline
\end{tabular}

ns No-significant. ${ }^{*}$ and ${ }^{* *}$ Significant at $5 \%$ and $1 \%$ probability levels, respectively. 
Influence of $\mathrm{Cu}$ on the dry matter yield of rice and common bean and the effects of $\mathrm{Cu}$ on uptake of macro and micronutrients are presented in Table 3. Copper application significantly increased dry matter yield of upland rice and common bean. However, dry matter yields of two species were decreased at the highest $\mathrm{Cu}$ concentration. Beneficial effect of $\mathrm{Cu}$ on yield of annual crops has been reported by Galrão (1999), grown on an Oxisol of central Brazil. At higher level, $\mathrm{Cu}$ toxicity is related to directly or indirectly affects the metabolic processes such as respiration, photosynthesis, $\mathrm{CO}_{2}$ fixation and gas exchange (Mocquot et al., 1996). Copper in excess interferes with the plant capacity of absorbing or translocating other nutrients, inhibiting root elongation and adversely affecting the permeability of the root cell membrane (Woolhouse \& Walker, 1981). Copper in excess also has a destructive effect on the integrity of the chloroplast membrane, leading to a decrease in photosynthetic activity (Mocquot et al., 1996).

Application of $\mathrm{Cu}$ significantly increased $\mathrm{Cu}$ concentrations in the shoots of two crop species. However, $\mathrm{Cu}$ accumulation was higher in the shoot of upland rice as compared with $\mathrm{Cu}$ shoot concentration of common bean. This means common bean was more efficient in dry matter production at low $\mathrm{Cu}$ concentration as compared with rice plants. This can also be confirmed on the basis of dry weight production. Copper had significant synergistic effect on the uptake of $\mathrm{P}, \mathrm{K}$, and $\mathrm{Mn}$ in the upland rice plants. However, concentration of $\mathrm{Ca}, \mathrm{Mg}$ and $\mathrm{Fe}$ were significantly decreased in these plants with the application of copper. Copper did not influence significantly uptake of $\mathrm{Zn}$ in rice plants. In bean plants, $\mathrm{Cu}$ appli-

Table 2. Influence of manganese on dry matter yield and uptake of macronutrients and micronutrients by corn and common bean plants.

\begin{tabular}{|c|c|c|c|c|c|c|c|c|c|}
\hline $\begin{array}{l}\text { Mn level } \\
\left(\mathrm{mg} \mathrm{kg}^{-1}\right)\end{array}$ & $\begin{array}{l}\text { Shoot dry wt. } \\
\text { (g four plants }^{-1} \text { ) }\end{array}$ & $P$ & $\begin{array}{c} \\
\end{array}$ & $\begin{array}{c}\mathrm{Ca} \\
\left.\mathrm{kg}^{-1}\right)\end{array}$ & $\mathrm{Mg}$ & $\mathrm{Zn}$ & $\mathrm{Cu}$ & $\begin{array}{c}\mathrm{Mn} \\
\left.\mathrm{kg}^{-1}\right)\end{array}$ & $\mathrm{Fe}$ \\
\hline & & \multicolumn{8}{|c|}{ Corn } \\
\hline 0 & 17.93 & 1.93 & 23.66 & 4.36 & 2.60 & 24 & 3.00 & 87 & 113 \\
\hline 10 & 20.83 & 1.63 & 23.00 & 4.26 & 2.40 & 20 & 2.00 & 147 & 117 \\
\hline 20 & 17.70 & 1.90 & 24.33 & 4.20 & 2.47 & 23 & 3.33 & 193 & 123 \\
\hline 40 & 20.00 & 1.70 & 22.00 & 3.93 & 2.53 & 21 & 2.67 & 363 & 117 \\
\hline 80 & 20.40 & 1.73 & 22.33 & 4.30 & 2.70 & 25 & 3.00 & 553 & 113 \\
\hline 160 & 19.80 & 1.50 & 23.33 & 3.43 & 2.37 & 23 & 2.33 & 1,067 & 90 \\
\hline 320 & 20.20 & 1.50 & 22.66 & 3.53 & 2.53 & 27 & 2.66 & 2,067 & 93 \\
\hline 640 & 13.77 & 1.63 & 25.00 & 2.93 & 2.03 & 32 & 2.66 & 3,567 & 110 \\
\hline $\mathrm{F}$ test & $* *$ & $* *$ & $\mathrm{~ns}$ & $* *$ & $* *$ & $* *$ & $* *$ & $* *$ & ns \\
\hline $\mathrm{CV}(\%)$ & 9 & 7 & 11 & 9 & 7 & 6 & 15 & 30 & 16 \\
\hline \multicolumn{10}{|c|}{ Regression } \\
\hline$\beta_{0}$ & 18.8858 & 1.8264 & 23.3422 & 4.2768 & 2.5061 & 22.0657 & 2.7901 & 68.5686 & 120.1196 \\
\hline$\beta_{1}$ & 0.01523 & -0.00201 & -0.00635 & -0.00362 & 0.00049 & 0.01233 & -0.00122 & 6.7715 & -0.17238 \\
\hline$\beta_{2}$ & -0.00004 & 0.000003 & 0.00001 & 0.000002 & -0.000002 & 0.000005 & 0.000002 & -0.00202 & 0.00024 \\
\hline $\mathrm{R}^{2}$ & $0.8100^{*}$ & $0.6355^{\mathrm{ns}}$ & $0.5256^{\mathrm{ns}}$ & $0.8545^{* *}$ & $0.7099 *$ & $0.8326^{*}$ & $0.0366^{\mathrm{ns}}$ & $0.9994 * *$ & $0.7784 *$ \\
\hline & & \multicolumn{8}{|c|}{ Common bean } \\
\hline 0 & 14.47 & 2.33 & 32.33 & 10.77 & 4.07 & 36 & 4.00 & 70 & 137 \\
\hline 10 & 14.77 & 2.17 & 31.67 & 10.93 & 4.17 & 35 & 5.33 & 210 & 180 \\
\hline 20 & 15.93 & 2.13 & 31.33 & 10.60 & 3.97 & 36 & 4.67 & 360 & 207 \\
\hline 40 & 17.23 & 2.26 & 32.33 & 11.10 & 4.23 & 36 & 5.00 & 520 & 170 \\
\hline 80 & 15.67 & 2.23 & 32.00 & 11.37 & 4.33 & 38 & 4.00 & 1,300 & 120 \\
\hline 160 & 14.30 & 2.07 & 38.67 & 10.36 & 4.27 & 42 & 5.33 & 1,933 & 123 \\
\hline 320 & 11.43 & 1.77 & 42.00 & 9.43 & 4.27 & 55 & 6.67 & 2,367 & 83 \\
\hline $\mathrm{F}$ test & $*$ & $\mathrm{~ns}$ & $* *$ & $\mathrm{~ns}$ & $\mathrm{~ns}$ & $* *$ & $\mathrm{~ns}$ & $* *$ & $\mathrm{~ns}$ \\
\hline $\mathrm{CV}(\%)$ & 11 & 17 & 7 & 7 & 5 & 6 & 26 & 29 & 49 \\
\hline \multicolumn{10}{|c|}{ Regression } \\
\hline$\beta_{0}$ & 15.3295 & 2.2676 & 31.1135 & 10.6923 & 4.0757 & 35.3849 & 4.6440 & 33.9744 & 175.2400 \\
\hline$\beta_{1}$ & 0.00937 & -0.00144 & 0.03743 & 0.00426 & 0.00264 & 0.02027 & -0.00122 & 16.78395 & -0.40949 \\
\hline$\beta_{2}$ & -0.00007 & - & -0.000008 & -0.00003 & -0.000006 & 0.00012 & 0.00002 & -0.02968 & 0.00037 \\
\hline $\mathrm{R}^{2}$ & $0.7641 *$ & $0.8335^{*}$ & $0.9131 * *$ & $0.6059^{\mathrm{ns}}$ & $0.5499^{\mathrm{ns}}$ & $0.9968 * *$ & $0.6877^{*}$ & $0.9932 * *$ & $0.6387^{\mathrm{ns}}$ \\
\hline
\end{tabular}

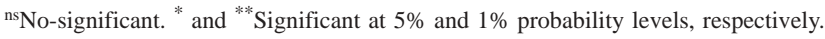


Table 3. Influence of copper on dry matter yield and uptake of macronutrients and micronutrients by upland rice and common bean plants.

\begin{tabular}{|c|c|c|c|c|c|c|c|c|c|}
\hline \multirow{3}{*}{$\begin{array}{c}\mathrm{Cu} \\
\left(\mathrm{mg} \mathrm{kg}^{-1}\right) \\
\end{array}$} & Shoot dry wt. & $\mathrm{P}$ & $\mathrm{K}$ & $\mathrm{Ca}$ & $\mathrm{Mg}$ & $\mathrm{Zn}$ & $\mathrm{Cu}$ & $\mathrm{Mn}$ & $\mathrm{Fe}$ \\
\hline & $\left(\mathrm{g}\right.$ four plants $\left.{ }^{-1}\right)$ & & $----(\mathrm{g} \mathrm{k}$ & $\left.\mathrm{g}^{-1}\right)$ & ----- & & $---\left(m_{s}\right.$ & $-1)-$ & ------ \\
\hline & \multicolumn{9}{|c|}{ Upland rice } \\
\hline 0 & 1.87 & 3.03 & 34.67 & 4.93 & 3.67 & 29 & 14 & 260 & 217 \\
\hline 2 & 1.87 & 3.17 & 35.33 & 4.43 & 3.60 & 29 & 17 & 327 & 143 \\
\hline 4 & 1.90 & 3.10 & 38.33 & 4.56 & 3.60 & 31 & 18 & 310 & 130 \\
\hline 8 & 2.03 & 3.27 & 33.33 & 4.87 & 3.63 & 30 & 21 & 293 & 127 \\
\hline 16 & 2.00 & 2.77 & 37.67 & 4.87 & 3.63 & 36 & 17 & 303 & 127 \\
\hline 32 & 1.87 & 2.93 & 36.67 & 4.77 & 3.60 & 31 & 20 & 327 & 113 \\
\hline 64 & 2.00 & 2.93 & 37.67 & 4.97 & 3.73 & 27 & 27 & 340 & 148 \\
\hline 96 & 0.30 & 1.63 & 26.67 & 6.10 & 4.43 & 35 & 34 & 163 & 227 \\
\hline $\mathrm{F}$ test & $* *$ & $* *$ & $* *$ & $* *$ & $* *$ & ns & $* *$ & ns & $*$ \\
\hline $\mathrm{CV}(\%)$ & 8 & 6 & 8 & 7 & 2 & 13 & 15 & 29 & 27 \\
\hline \multicolumn{10}{|l|}{ Regression } \\
\hline$\beta_{0}$ & 1.8025 & 3.0398 & 34.7534 & 4.7570 & 3.6232 & 30.8922 & 16.6087 & 280.7075 & 164.6425 \\
\hline$\beta_{1}$ & 0.02380 & 0.00856 & 0.20496 & -0.00857 & -0.00528 & -0.04641 & 0.10622 & 3.5814 & -2.79529 \\
\hline$\beta_{2}$ & -0.00039 & -0.00023 & -0.00294 & 0.00022 & 0.00027 & 0.00076 & 0.00078 & -0.04890 & 0.03648 \\
\hline $\mathrm{R}^{2}$ & $0.9137^{* *}$ & $0.8504^{* *}$ & $0.7729^{*}$ & $0.8571^{* *}$ & $0.9956^{* *}$ & $0.1122^{\mathrm{ns}}$ & $0.9221^{* *}$ & $0.8158^{*}$ & $0.6892^{*}$ \\
\hline & \multicolumn{9}{|c|}{ Common bean } \\
\hline 0 & 5.03 & 1.87 & 35.33 & 18.30 & 8.20 & 19 & 4.33 & 97 & 190 \\
\hline 2 & 5.70 & 1.93 & 36.67 & 18.27 & 8.30 & 18 & 5.00 & 63 & 203 \\
\hline 4 & 6.63 & 2.13 & 34.33 & 18.43 & 8.23 & 17 & 6.33 & 67 & 403 \\
\hline 8 & 6.63 & 1.90 & 39.33 & 18.60 & 8.23 & 19 & 7.67 & 77 & 193 \\
\hline 16 & 5.00 & 1.90 & 40.00 & 20.33 & 8.67 & 21 & 6.33 & 73 & 163 \\
\hline 32 & 4.60 & 1.77 & 27.67 & 18.53 & 8.33 & 20 & 8.00 & 80 & 190 \\
\hline 64 & 4.70 & 1.73 & 38.00 & 17.63 & 8.40 & 20 & 10.33 & 67 & 233 \\
\hline 96 & 0.63 & 1.93 & 28.33 & 19.50 & 8.53 & 25 & 15.33 & 37 & 280 \\
\hline $\mathrm{F}$ test & $* *$ & ns & $* *$ & $\mathrm{~ns}$ & ns & ns & $* *$ & $* *$ & $\mathrm{~ns}$ \\
\hline $\mathrm{CV}(\%)$ & 34 & 7 & 11 & 6 & 4 & 17 & 11 & 20 & 49 \\
\hline \multicolumn{10}{|l|}{ Regression } \\
\hline$\beta_{0}$ & 5.7182 & 1.9896 & 36.2765 & 18.7271 & 8.2708 & 18.5881 & 5.5117 & 75.1137 & 244.9650 \\
\hline$\beta_{1}$ & 0.01204 & -0.00927 & -0.00018 & -0.01188 & 0.00536 & 0.01400 & 0.05815 & 0.27063 & -2.50400 \\
\hline$\beta_{2}$ & -0.00064 & 0.00009 & -0.00071 & 0.00016 & -0.00003 & 0.00048 & 0.00043 & -0.00681 & 0.03074 \\
\hline $\mathrm{R}^{2}$ & $0.8374^{*}$ & $0.5059^{\mathrm{ns}}$ & $0.2537^{\mathrm{ns}}$ & $0.0443^{\mathrm{ns}}$ & $0.2967^{\mathrm{ns}}$ & $0.7468^{*}$ & $0.9370^{* *}$ & $0.6274^{\mathrm{ns}}$ & $0.1302^{\text {ns }}$ \\
\hline
\end{tabular}

ns No-significant. ${ }^{*}$ and ${ }^{* *}$ Significant at $5 \%$ and $1 \%$ probability levels, respectively.

cation significantly increased uptake of $\mathrm{Zn}$ and had no significant effect on uptake of $\mathrm{P}, \mathrm{K}, \mathrm{Ca}, \mathrm{Mg}, \mathrm{Mn}$ and iron. Lexmond \& Vorm (1981), Ouzounidou et al. (1995) and Mocquot et al. (1996) reported synergistic, antagonistic or no effect of $\mathrm{Cu}$ on the uptake of macro and micronutrients depending on crop species and concentration of copper.

\section{Conclusions}

1. Zinc, $\mathrm{Mn}$ and $\mathrm{Cu}$ requirements in annual crops grown on Oxisols vary among crop species.

2. Upland rice responds to $\mathrm{Zn}$ fertilization but for common bean, $\mathrm{Zn}$ application does not improve yield and has negative effect.

3. Corn and common bean yields improve with Mn application.
4. Copper fertilization increases dry matter yield of upland rice and common bean.

5. Rice has higher concentration of $\mathrm{Cu}$ as compared with common bean for the maximum dry matter yield.

6. Interactions of $\mathrm{Zn}, \mathrm{Mn}$, and $\mathrm{Cu}$ with macro and micronutrients are either synergistic, antagonistic or have no effects, depending on crop species and nutrients under investigation.

\section{References}

BALIGAR, V. C.; FAGERIA, N. K. Nutrient use efficiency in plants. Communications in Soil Science and Plant Analysis, New York, v. 32, p. 921-950, 2001.

BARBOSA FILHO, M. P.; SILVA, O. F. da. Adubação e calagem para o feijoeiro irrigado em solo de cerrado. 
Pesquisa Agropecuária Brasileira, Brasília, v. 35, n. 7, p. 1317-1324, jul. 2000.

BREMNER, J. M.; MULVANEY, C. S. Nitrogen-total. In: PAGE, A. L.; MILLER, R. H.; KENNEY, D. R. (Ed.). Methods of soil analysis. 2. ed. Madison: American Society of Agronomy, 1982. part 2, p. 595-624. (Agronomy, 9).

CAKMAK, I.; TORUN, B.; ERENOGLU, B.; OZTURK, L.; MARSCHNER, H.; KALAYCI, M.; EKIZ, H.; YILMAZ, A. Morphological and physiological differences in the response of cereals to zinc deficiency. Euphytica, Amsterdam, v. 100, p. 349-357, 1998.

CHINNERY, L. E.; HARDING, C. P. The effect of ferrous iron on the uptake of manganese by Juncus effusus. Annals of Botany, London, v. 46, p. 409-412, 1980.

COUTO, C.; NOVAIS, R. F.; TEIXEIRA, J. L.; BARROS, N. F.; NEVES, J. C. L. Níveis críticos de zinco no solo e na planta para o crescimento de milho em amostras de solos com diferentes valores de fator capacidade. Revista Brasileira de Ciência do Solo, Campinas, v. 16, p. 7987, 1992.

COUTO, E. G.; KLAMT, E. Variabilidade espacial de micronutrientes em solo sob pivô central no sul do Estado de Mato Grosso. Pesquisa Agropecuária Brasileira, Brasília, v. 34, n. 12, p. 2321-2329, dez. 1999.

EMBRAPA. Serviço Nacional de Levantamento e Conservação de Solos (Rio de Janeiro, RJ). Manual de métodos de análise de solo. 2. ed. rev. atual. Rio de Janeiro, 1997. 212 p.

ERNANI, P. R.; BAYER, C.; MAESTRI, L. Corn yield as affected by liming and tillage system on an acid Brazilian Oxisol. Agronomy Journal, Madison, v. 94, p. 305309, 2002.

FAGERIA, N. K. Resposta de arroz de terras altas à correção de acidez em solo de cerrado. Pesquisa Agropecuária Brasileira, Brasília, v. 35, n. 11, p. 23032307, nov. 2000.

FAGERIA, N. K.; BALIGAR, V. C. Improving nutrient use efficiency of annual crops in Brazilian acid soils for sustainable crop production. Communications in Soil Science and Plant Analysis, New York, v. 32, p. 13031319, 2001.

FAGERIA, N. K.; BALIGAR, V. C. Response of common bean, upland rice, corn, wheat and soybean to fertility of an Oxisol. Journal of Plant Nutrition, New York, v. 20, p. 1279-1289, 1997.
FAGERIA, N. K.; BALIGAR, V. C.; CLARK, R. B. Micronutrients in crop production. Advances in Agronomy, New York, v. 77, p. 189-272, 2002.

FAGERIA, N. K.; BALIGAR, V. C.; JONES, C. A. Growth and mineral nutrition of field crops. 2. ed. New York: M. Dekker, 1997. 624 p.

GALRÃO, E. Z. Efeito de micronutrientes e do cobalto na produção e na composição química do arroz, milho e soja em solo de cerrado. Revista Brasileira de Ciência do Solo, Campinas, v. 8, p. 111-116, 1984.

GALRÃO, E. Z. Métodos de aplicação de cobre e avaliação da disponibilidade para a soja num Latossolo Vermelho Amarelo franco-argilo-arenoso fase cerrado. Revista Brasileira de Ciência do Solo, Viçosa, MG, v. 23, p. 265272, 1999.

GALRÃO, E. Z. Micronutrientes e cobalto no rendimento da soja em solo de cerrado. Revista Brasileira de Ciência do Solo, Campinas, v. 15, p. 117-120, 1991.

LEACH, W.; TAPER, C. D. Studies in plant mineral nutrition II: the absorption of Fe and Mn by dwarf kidney beans, tomato, and onion from culture solutions. Canadian Journal of Botany, Ottawa, v. 63, p. 604-608, 1954.

LEXMOND, T. M.; VORM, P. D. J. van der. The effect of $\mathrm{pH}$ on copper toxicity to hydroponically grown maize. Netherlands Journal of Agricultural Science, Wageningen, v. 29, p. 217-238, 1981.

MOCQUOT, B.; VANGRONSVELD, J.; CLIJSTERS, H.; $\mathrm{MENCH}, \mathrm{M}$. Copper toxicity in young maize (Zea mays L.) plants: effects on growth, mineral and chlorophyll contents, and enzyme activities. Plant and Soil, Dordrecht, v. 182, p. 287-300, 1996.

MORAES, J. F. V.; RABELO, N. A. Um método simples para a digestão de amostras de planta. Goiânia: EmbrapaCNPAF, 1986. 10 p. (Documentos, 12).

NOVAIS, R. F.; NEVES, J. C. L.; BARROS, N. F.; SEDIYAMA, T. Deficiência de manganês em plantas de soja cultivadas em solos de cerrado. Revista Brasileira de Ciência do Solo, Campinas, v. 13, p. 199-204, 1989.

OLIVEIRA JÚNIOR, J. A. de; MALAVOLTA, E.; CABRAL, C. P. Efeitos do manganês sobre a soja cultivada em solo de cerrado do Triângulo Mineiro. Pesquisa Agropecuária Brasileira, Brasília, v. 35, n. 8, p. 16291636, ago. 2000.

OUZOUNIDOU, G.; CIAMPOROVA, M.; MOUSTAKAS, M.; KARRTAGLIS, S. Response of maize plants to copper stress I: growth, mineral content and ultrastructure of roots. Environmental and Experimental Botany, Oxford, v. 35, p. 167-176, 1995. 
ROBSON, A. D.; PITMAN, J. B. Interactions between nutrients in higher plants. In: LÄUCHLI, A.; BIELESKI, R. L. (Ed.). Inorganic plant nutrition. New York: Springer, 1983. p. 147-180. (Encyclopedia of Plant Physiology, 1).

SUMNER, M. E.; FARINA, P. W. Phosphorus interactions with other nutrients and lime in field cropping systems. Advances in Soil Science, New York, v. 5, p. 201236, 1986.
WILKINSON, S. R.; GRUNES, D. L.; SUMNER, M. E. Nutrient interactions in soil and plant nutrition. In: SUMNER, M. E. (Ed.). Handbook of soil science. Boca Raton: CRC Press, 2000. p. 89-112.

WOOLHOUSE, H. M.; WALKER, S. The physiological basis of copper toxicity and copper tolerance in higher plants. In: LONERAGAN, J. F.; ROBSON, A. D.; GRAHAM, R. D. (Ed.). Copper in soils and plants. Sydney: Academic, 1981. p. 265-285. 